\title{
Hubungan Dukungan Suami dengan Kondisi Fisik dan Kondisi Psikososial Ibu Primigravida
}

\section{The Influence of Husband Support with Physical Conditions and Psychosocial Conditions in Primigravida Mothers}

\author{
Ariani Fatmawati ${ }^{1}$, Asrie Alifah ${ }^{2}$, dan Nina Gartika ${ }^{3}$ \\ 1. Universitas 'Aisyiyah Bandung, Indonesia \\ 2. Universitas 'Aisyiyah Bandung, Indonesia \\ 3. Universitas 'Aisyiyah Bandung, Indonesia \\ Email Korespondensi : rianiners@gmail.com
}

\begin{abstract}
Abstrak
Latar belakang: Kehamilan merupakan proses adaptasi ibu dengan peran dan tugas baru. Terjadi banyak perubahan seperti perubahan fisik dan psikologis. Adaptasi terhadap segala bentuk perubahan dan tugas baru memerlukan dukungan suami.

Tujuan: Untuk mengetahui hubungan dukungan suami dengan kondisi fisik dan kondisi psikososial pada ibu primigravida.

Metode: Metode penelitian kuantitatif korelatif dengan desain cross-sectional. Jumlah total sampel adalah 86 ibu primigravida dengan cara purposive sampling. Kriteria inklusi ibu primigravida, sehat fisik dan tinggal dengan suami atau pasangan. Pengambilan data menggunakan kuesioner dukungan suami, kondisi fisik dan kondisi psikologis ibu hamil. serta data dianalis dengan uji chisquare.

Hasil: Menunjukkan bahwa terdapat hubungan yang bermakna antara dukungan suami dengan kondisi fisik dan psikososial ibu primigravida dengan $p$-value 0,000 .

Kesimpulan: Ibu primigravida yang tidak mendapatkan dukungan berisiko mengalami gangguan fisik dan psikososial, terutama pada ibu yang usianya masih remaja.
\end{abstract}

Kata kunci: Dukungan suami; Ibu hamil; Kondisi fisik; Kondisi psikososial; Primigravida

\begin{abstract}
Background: Pregnancy is a process of adapting mothers to new roles and tasks. There are many changes such as physical and psychological changes. Adaptation to all forms of change and new tasks requires the support of a husband.

Objective: To determine the relationship of husband support with physical conditions and psychosocial conditions in primigravida mothers.

Method: quantitative correlative research method with cross-sectional design. The total sample was 86 primigravida mothers by purposive sampling. Criteria for inclusion of primigravida mothers, physically fit, and living with a husband or partner. Data collection using the husband's support questionnaire, physical condition, and psychological condition of pregnant women. and data analyzed with the chi-square test.

Results: It shows that is a significant relationship between husband's support with the physical and psychosocial conditions of primigravida mothers with a p-value of 0.000 .

Conclusion: Primigravida mothers experience physical condition and psychosocial conditions which are at risk so the husband's support is needed.
\end{abstract}

Keywords: Husband support; Physical condition; Pregnant mother; Primigravida; Psychosocial condition 


\section{PENDAHULUAN}

Kehamilan merupakan suatu pengalaman yang sangat berharga dan membahagiakan bagi seorang wanita terutama bagi wanita yang baru pertama kali hamil. Primigravida adalah pengalaman pertama seorang wanita mengalami masa kehamilan. Ibu primigravida sering merasa khawatir berlebihan terutama dengan munculnya perubahan-perubahan selama kehamilan. Perubahan yang terjadi pada masa kehamilan adalah perubuahan fisik, dan perubahan psikologis (1). Perubahan ini diakibatkan karena terjadi peningkatan hormon estrogen dan progesteron (2).

Perubahan fisik ibu hamil terjadi pada semua sistem tubuh ibu hamil, seperti perubahan bentuk tubuh terutama pada bagian perut, bokong, payudara dan wajah, mengalami morning sickness, perubahan warna kulit, sering kencing, mudah lelah dan sulit tidur karena perut yang semakin membesar, sesak, edema, nyeri pinggang dan punggung, dan gatal di daerah perut pada trimester ketiga sering dikeluhkan oleh ibu (2). Perubahan fisik yang dialami akan memengaruhi kondisi psikologis ibu. Ibu primigravida mengalami perubahan psikologis negatif (3). Hal ini dikarenakan ibu primigravida belum memiliki pengalaman, berbeda pada ibu multigravida yang telah memiliki pengalaman hamil sebelumnya mengalami perubahan psikologis positif (4). Perubahan psikologis yang dialami oleh ibu primigravida seperti ibu mudah marah, meminta perhatian dan kasih sayang yang lebih, lebih sensitif, takut dan cemas (5).

Periode perubahan dan penyesuaian yang ditandai dengan perkembangan krisis disebut dengan adaptasi maternal. Hal ini, dapat membuat wanita menjadi stress karena harus mempersiapkan diri memiliki peran dan tanggung jawab baru terutama pada ibu kehamilan pertama (primigravida) (2). Ada empat tugas baru bagi seorang wanita selama hamil menurut Reva Rubin yaitu keamanan untuk diri dan janinnya, menyiapkan diri menjadi seorang ibu, belajar menerima dan memberi perhatian, dan berkomitmen dengan janinnya selama kehamilan (5). Tugas perkembangan wanita saat hamil memerlukan pengetahuan dan keyakinan yang cukup agar dapat bertanggung jawab pada diri sendiri dan janinnya (6).

Pemenuhan tugas baru selama kehamilan pada ibu primigravida dapat meningkatkan kecemasan. Hal ini disebabkan karena ibu primigravida memiliki pengetahuan yang kurang mengenai kehamilan, kelahiran dan nifas. Pengetahuan ibu primigravida selama kehamilan diantaranya kurangnya pengetahuan mengenai kunjungan antenatal care (7), kurangnya pengetahuan tentang tanda bahaya kehamilan (8), dan rasa cemas meningkat pada saat akan melahirkan (9). Kehamilan akan membuat pasangan beradaptasi dengan perkembangan keluarga hadirnya anggota keluarga baru sehingga peran pasangan akan bertambah dan perubahan hubungan pasangan (10).

Perubahan secara fisik dan psikologis selama kehamilan membutuhkan dukungan sosial dan dukungan keluarga. Salah satu dukungan keluarga adalah dukungan suami. Peran suami merupakan dukungan utama selama masa kehamilan bagi ibu hamil, karena suami merupakan orang terdekat ibu hamil. Dukungan suami selama kehamilan adalah pada kunjungan antenatal care (7), memberikan motivasi kepada istri selama kehamilan, persalinan dan nifas (11), dukungan pada saat akan melahirkan (12).

Dukungan suami yang diterima oleh ibu primigravida dapat memberikan ketenangan selama proses kehamilan. Dukungan suami dibutuhkan untuk mendukung pencapaian peran menjadi seorang ibu selam kehamilan (13). Dukungan keluarga terutama suami memiliki hubungan dengan proses adaptasi kehamilan. Adaptasi kehamilan terhadap perubahan fisik dan psikologis selama kehamilan (14).

Berdasarkan penelitian diatas, dukungan suami sangat berpengaruh pada adaptasi ibu hamil untuk menerima perubahan fisik dan psikologis pada masa kehamilan. Dukungan diperlukan agar ibu primigravida dapat menjalani kehamilan dengan baik dan bahagia. 
Terdapat perbedaan antara penelitian yang akan dilakukan dengan penelitian sebelumnya adalah pada respondennya yang merupakan ibu primigravida. Tujuan penelitian ini adalah untuk mengidentifikasi hubungan dukungan suami dengan kondisi fisik dan psikologis ibu primigravida.

\section{METODE}

Penelitian ini menggunakan pendekatan kuantitatif korelatif dengan desain cross sectional. Tujuan penelitian ini adalah untuk mengetahui hubungan dukungan suami dengan kondisi fisik ibu hamil primigravida dan hubungan dukungan suami dengan kondisi psikososial ibu primigravida. Penelitian dilakukan di Puskesmas Kab. Bandung pada bulan Juli-September 2019. Pengambilan sampel dilakukan dengan cara purposive sampling. Sampel dalam penelitian ini adalah ibu primigravida sebanyak 86 orang. Perhitungan sampel menggunakan rumus deskriptif korelatif (15). Kriteria inklusi yaitu ibu primigravida, sehat fisik dan tinggal dengan suami atau pasangan. Kriteria eksklusi yaitu responden memiliki riwayat gangguan jiwa sebelum hamil, dan responden mengalami kehamilan diluar rahim.

Pengumpulan data menggunakan tiga kuesioner yaitu dukungan suami, kondisi fisik dan psikologis ibu hamil. Dukungan suami adalah perhatian yang diberikan oleh suami baik secara fisik, psikologis, emosional dn finansial yang membuat ibu merasa aman dan nyaman. Kondisi fisik merupakan perubahan fisik yang terjadi selama kehamilan. Kondisi psikosoial merupakan suatu kondisi psikologis dan sosial ibu primigravida yang dapat mengganggu kondisi emosional. Kuesioner dukungan suami terdiri dari 9 item pertanyaan dengan skala likert. Skor tertinggi 36 dan terendah 9. Hasil dikategorikan menjadi dukungan suami baik jika skor $>24$ dan dikatakan dukungan suami kurang jika skor $\leq 24$. Kuesioner kondisi fisik terdiri dari 12 item pertanyaan dengan skala likert. Skor tertinggi 44 dan terendah 11. Skor $\leq 32$ tidak ada gangguan fisik dan $>32$ mengalami gangguan fisik. Kuesioner terakhir adalah kuesioner kondisi psikososial ibu hamil yang terdiri dari 19 item pertanyaan dengan skala likert. Skor tertinggi 76 dan terendah 19. Skor $>56$ berisiko dan $\leq 56$ tidak berisiko. Kuesioner penelitian dibuat sendiri. Sebelum disebarkan kepada responden, maka kuesioner yang dibuat dilakukan uji validitas dan reliabilitas terlebih dahulu. Uji validitas menggunakan pearson product moment dan uji reliabilitas dengan rumus $\alpha$-Cronbach. Hasil uji validitas kuesioner dukungan suami 0,514, kondisi fisik 0,859, dan kondisi psikososial 0,879. Hasil uji reliabilitas dukungan suami 0,690, kondisi fisik 0,854 dan kondisi psikososial 0,931.

Pengambilan data dilakukan di Poli KIA dan posyandu sesuai dengan jadwal dengan dibantu oleh 2 orang asisten pengambil data. Asisten pengambil data adalah petugas puskesmas yaitu bidan dengan latar belakang pendidikan D3 atau D4 kebidanan. Analisis data menggunakan SPSS. Analisis univariate untuk mengetahui distribusi frekuensi dukungan suami, kondisi fisik dan psikososial ibu primigravida. Analisis korelasi menggunakan analisis chi-square. Penelitian ini mendapatkan persetujuan lolos uji etik dari Komite Etik Penelitian Kesehatan STIKes Aisyiyah Bandung dengan nomor: 06/KEP.02/STIKes-AB/V/2019. Responden diberikan penjelasan mengenai penelitian yang akan dilakukan, jika setuju maka responden di minta untuk menandatangani surat informed consent dan mengisi kuesioner. Peneliti akan menjaga kerahasiaan responden dengan hanya mencantumkan inisial dan kode pada lembar kuesioner.

\section{HASIL}

Hasil analisis univariat dilakukan untuk mengetahui distribusi frekuensi dukungan suami, kondisi fisik dan psikososial ibu primigravida. Hasil dapat dilihat pada tabel dibawah ini: 
Tabel 1. Distribusi Frekuensi Dukungan Suami, Kondisi Fisik dan Psikologis Ibu Primigravida $(\mathbf{n}=\mathbf{8 6})$

\begin{tabular}{lcc}
\hline \multicolumn{1}{c}{ Variabel } & f & $\%$ \\
\hline Dukungan Suami & & \\
Baik & 46 & 53,5 \\
Kurang & 40 & 46,5 \\
\hline Kondisi Fisik & & \\
Ada Gangguan fisik & 27 & 31,4 \\
Tidak ada Gangguan Fisik & 59 & 68,6 \\
\hline Kondisi Psikologis & & \\
Berisiko & 55 & 64 \\
Tidak Berisiko & 31 & 36 \\
\hline Total & 86 & 100 \\
\hline
\end{tabular}

Berdasarkan tabel diatas, lebih dari setengahnya ibu primigravida mendapatkan dukungan suami baik sebanyak 53,5\%, sebagian besar ibu hamil primigravida tidak mengalami gangguan fisik sebanyak $68,8 \%$ dan sebagian besar ibu mengalami kondisi psikososial yang berisiko sebanyak $64 \%$.

Hasil analisis bivariat yang dilakukan untuk mengetahui hubungan dukungan suami dengan kondisi fisik dan psikologis ibu primigravida dapat terlihat pada tabel dibawah ini:

Tabel 2. Hubungan Dukungan Suami dengan Kondisi Fisik dan Kondisi Psikososial Ibu Primigravida $(\mathbf{n}=\mathbf{8 6})$

\begin{tabular}{|c|c|c|c|c|c|}
\hline \multirow[t]{3}{*}{ Variabel } & \multicolumn{4}{|c|}{ Dukungan Suami } & \multirow[t]{3}{*}{ p-value } \\
\hline & \multicolumn{2}{|c|}{ Baik } & \multicolumn{2}{|c|}{ Kurang } & \\
\hline & $\mathrm{f}$ & $\%$ & $f$ & $\%$ & \\
\hline Kondisi Fisik & & & & & 0,000 \\
\hline Tidak Mengalami & 5 & 10,8 & 22 & 55 & \\
\hline Gangguan Fisik & & & & & \\
\hline $\begin{array}{l}\text { Mengalami Gangguan } \\
\text { Fisik }\end{array}$ & 41 & 89,1 & 18 & 45 & \\
\hline Kondisi Psikososial & & & & & 0,000 \\
\hline Tidak Berisiko & 46 & 100 & 31 & 77,5 & \\
\hline Berisiko & 0 & 0 & 9 & 22,5 & \\
\hline
\end{tabular}

Berdasarkan tabel diatas, menunjukkan bahwa terdapat hubungan antara dukungan suami dengan kondisi fisik dan kondisi psikososial ibu primigravida dengan $p$-value $=0,000$.

\section{PEMBAHASAN}

Berdasarkan hasil menunjukkan bahwa terdapat hubungan antara dukungan suami dengan kondisi fisik dan psikososial ibu primigravida $p$-value $=0,000$. Sebagian besar tidak mengalami gangguan fisik sebanyak $68,6 \%$. Sedangkan untuk dukungan suami yang diterima ibu primigravida berada pada dukungan suami baik sebanyak 53,5\%. Dukungan suami memiliki arti bagi ibu hamil dalam menjaga kondisi kesehatan selama kehamilan (16).

Perubahan fisik yang dialami oleh ibu hamil terutama pada bentuk tubuh. Perubahan bentuk tubuh seperti berat badan meningkat, perut membesar, edema, dan ada beberapa ibu hamil yang mengalami hiperpigmentasi pada kulit (2), morning sickness, payudara membesar dan kencang, uterus membesar dan berat badan naik (17). Hal ini menyebabkan perubahan citra tubuh pada ibu hamil. Perubahan citra tubuh ini ada yang diterima positif maupun 
negatif. Jika perubahan ini diterima dengan positif, maka ibu tidak akan terlalu banyak mengeluh atau merasa terganggu dengan kondisi seperti ini. Meskipun ibu mengalami perubahan fisik tetapi citra tubuh ibu sebagian besar positif (18).

Perubahan fisik selama kehamilan akan berpengaruh pada kondisi psikososial. Bentuk kondisi psikososial selama hamil adalah cemas, stress, takut dan perubahan citra tubuh (13). Perasaan cemas muncul biasanya karena kehamilan pertama (primigravida) sehingga ibu belum memiliki pengalaman, pengetahuan yang kurang, usia ibu yang masih muda, hidup sendiri tanpa pasangan dan keluarga serta perasaan kurangnya dukungan (19).

Beberapa bentuk dukungan suami untuk ibu hamil seperti mengambil air, menyiapkan makanan bergizi, menemani istri untuk antenatal care, mengingatkan istri untuk tidak bekerja berat, dan menyiapkan uang untuk transfortasi dan perawatan (20). Hasil penelitian lain menunjukkan bahwa bentuk dukungan suami secara finansial dengan membelikan buah dan sayur, membantu mengerjakan pekerjaan rumah dan memberikan kata-kata yang baik (21), memberikan rasa aman dan nyaman dengan sentuhan dan belaian serta kata-kata yang meningkatkan motivasi (22).

Dukungan emosional dan mental yang diberikan oleh suami dapat membantu ibu hamil primigravida menyelesaikan masalah selama hamil, mengatasi stress, meningkatkan kesiapan menjadi ibu, dan membantu mencari sumber lain untuk menyelesaikan permasalahan atau keluhan (23). Dukungan suami dengan menjadi pasangan yang baik selama kehamilan pada awal trimester dapat melindungi dari beberapa stressor (24).

Dukungan fisik, emosional, sosial dan ekonomi, memotivasi ibu hamil untuk ke pelayanan antenatal sehingga dapat mengidentifikasi bahaya kehamilan sejak awal (25). Bentuk dukungan suami yang lain yaitu dengan mengantar istri melakukan antenatal care (7), menginformasikan dan mengantarkan ibu untuk mengikuti kelas ibu hamil (26), meningkatkan kepatuhan ibu hamil dalam mengkonsumsi tablet besi (27). Diakhir kehamilan, dukungan suami diperlukan pada saat proses persalinan dengan mendampingi ibu selama proses persalinan (28).

Manfaat dukungan emosional dari suami dan keluarga dapat mencegah kejadian depresi antenatal (29). Hasil penelitian ini sejalan dengan penelitian sebelumnya yang menyatakan bahwa dukungan suami menurunkan angka depresi selama kehamilan (30).

\section{SIMPULAN}

Hasil penelitian menunjukkan bahwa dukungan suami pada ibu primigravida sebagian besar memberikan dukungan yang baik. Ibu primigravida memerlukan dukungan suami atau pasangan saat hamil karena ibu primigravida sebagian besar mengalami gangguan kondisi fisik seperti perubahan bentuk tubuh dan banyaknya perubahan fisik yang dikeluhkan. Selain kondisi fisik, kondisi psikososial pada ibu primigravida sebagian besar berisiko.

\section{UCAPAN TERIMA KASIH}

Ucapan terima kasih disampaikan kepada Kepala Dinas Kesehatan Kab. Bandung, Kepala Puskesmas Nagrak, Kepala Puskesmas Cimaung dan Kepala Puskesmas Cikalong.

\section{SARAN}

Hasil penelitian ini diharapkan dapat mendorong puskesmas untuk memberikan penyuluhan kepada masyarakat bahwa dukungan suami sangatlah penting diberikan kepada ibu hamil. Dapat dijadikan materi pembelajaran pada mata kuliah Keperawatan Maternitas. Peneliti selanjutnya diharapkan dapat melakukan penelitian khusus kepada responden ibu hamil berisiko. 


\section{DAFTAR PUSTAKA}

1. Janiwarty B, Pieter HZ. Pendidikan psikologi untuk bidan suatu teori dan terapannya. Yogyakarta Rapha Publ. 2013;

2. Lowdermilk DL, Perry SE, Cashion K. Keperawatan Maternitas. 8 Buku 1. Singapore: Elsevier; 2013.

3. Sandy UF, Sari TP. Gambaran Tentang Tingkat Pengetahuan Ibu Hamil Trimester III Tentang Hubungan Seksual Selama Kehamilan. Profesi (Profesional Islam. 2012;9.

4. Rustikayanti RN, Kartika I, Herawati Y. Perubahan Psikologis pada Ibu Hamil Trimester III. Southeast Asian J Midwifery. 2016;2(1):45-9.

5. Bear M, Bonnheim M, Gallardo C, Kruse CM, Landers K, Lanzoni A, et al. Nursing Key Topics Review Maternity. Singapura: Elsevier; 2017.

6. McNamara J, Townsend ML, Herbert JS. A Systemic review of Maternal Wellbeing and its Relationship with Maternal Fetal Attachment and Early Postpartum Bonding. PLoS One. 2019;14(7):1-28.

7. Evayanti Y. Hubungan Pengetahuan Ibu Dan Dukungan Suami Pada Ibu Hamil Terhadap Keteraturan Kunjungan Antenatal Care (ANC) Di Puskesmas Wates Lampung Tengah Tahun 2014. J Kebidanan [Internet]. 2015;1(2):81-90. Available from: http://malahayati.ac.id/wp-content/uploads/2016/03/18-60-1-PB.pdf

8. Damanik F, Restuastuti T, Noviardi. Tingkat Pengetahuan Ibu Primigravida tentang Tanda Bahaya Kehamilan Sebelum dan Sesudah Penyuluhan di Wilayah Kerja Puskesmas Rejosari. Jom FK. 2015;2(2):1-13.

9. Istikhomah H, Mumpuni DAP. Kesiapan Psikologis Ibu Hamil Trimester III dalam Persiapan Persalinan Pasca Relaksasi Hypnobirthing. J Kebidanan dan Kesehat Tradis. 2016;1(1):28-33.

10. Hapsari VD, Sudarmiati S. Pengalaman Seksualitas Ibu Hamil di Puskesmas Pondok Aren Tangerang. J Ners. 2011;6(1):76-84.

11. Hutagaol A. Hubungan Motivasi Suami pada Ibu Hamil terhadap Pemeriksaan Kehamilan (ANC) di Rumah Sakit Imelda Pekerja Indonesia Medan. J Ilm Keperawatan IMELDA. 2015;1(1):67-70.

12. Mukhadiono, Subagyo W, Wahyuningsih D. Hubungan antara Dukungan Suami dengan Tingkat Kecemasan pada Ibu Primigravida Timester III dalam Menghadapi Persalinan. J Keperawatan Soedirman [Internet]. 2015;10(1):17-23. Available from: http://jks.fikes.unsoed.ac.id/index.php/jks/article/view/185/86gmbran

13. Pangesti WD. Adaptasi Psikologis Ibu Hamil Dalam Pencapaian Peran Sebagai Ibu Di Puskesmas Kembaran II Kabupaten Banyumas. Viva Med J Kesehatan, Kebidanan dan Keperawatan. 2018;10(1):13-21.

14. Astuti AB, Santosa SW, Utami MS. Hubungan Antara Dukungan Keluarga. J Psikol. 2000;(2):84-95.

15. Dahlan MS. Statistik untuk Kedokteran dan Kesehatan. Jakarta: Salemba Medika; 2011.

16. Melati R, Raudatussalamah. Hubungan Dukungan Sosial Suami Dengan Motivasi Dalam Menjaga Kesehatan Selama Kehamilan. J Psikol UIN Sultan Syarif Kasim Riau. 2012;8(Desember):111-8.

17. Wulandari P. Pengalaman Psikologis Kehamilan Pranikah Pada Usia Remaja Di Keluarahan Purwosari Kecamatan Mijen. J Holist Nurs Sci. 2019;6(2):21-30.

18. Gani RR, Bidjuni H, Lolong J. Hubungan Perubahan Citra Tubuh (Body Image) dengan Depresi pada Ibu Hamil Trimester II dan Trimester III di Puskesmas Tilango Kabupaten Gorontalo. J Keperawatan UNSRAT. 2014;2(2).

19. Deklava L, Lubina K, Circenis K, Sudraba V, Millere I. Causes of Anxiety during Pregnancy. Procedia - Soc Behav Sci [Internet]. 2015;205:623-6. Available from: 
http://dx.doi.org/10.1016/j.sbspro.2015.09.097

20. Reddamma G. Knowledge of Husbands og Primigravidae Regarding Antenatal Care. Nurs Joutnal India. 2010;11(8):145-52.

21. Mosunmola S, Adekunbi F, Foluso O. Women's Perception of Husbands' Support During Pregnancy, Labour and Delivery. IOSR J Nurs Heal Sci. 2014;3(3):45-50.

22. Jhaquin A. Psikologi Untuk Kebidanan. Yogyakarta: Nuha Medika; 2010.

23. Highet N, Stevenson AL, Purtell C, Coo S. Qualitative Insights Into Women's Personal Experiences of Perinatal Depression and Anxiety. Women and Birth [Internet]. 2014;27(3):179-84. Available from: http://dx.doi.org/10.1016/j.wombi.2014.05.003

24. Røsand GB, Slinning K, Eberhard-gran M, Røysamb E, Tambs K. Partner Relationship Satisfaction and Maternal Emotional Distress in Early Pregnancy. BMC Public Health. 2011;11(161).

25. Iliyasu Z, Abubakar I., Galadanci H., Aliyu M. Birth Preparedness, Complication Readiness and Fathers'Participation in Maternity Care in a Northern Nigerian Community. African J Reprod Heal Mar. 2010;14(1):2-5.

26. Septiani R. Pengetahuan, Sikap Ibu Hamil dan Dukungan Suami dengan Keikutsertaan Ibu Hamil dalam Kelas Ibu Hamil di Puskesmas Kota Metro Lampung. J Kesehat. 2013;4(2):408-15.

27. Khatijah SA, Kesihatan Masyarakat J, Perubatan F, Kebangsaan Malaysia U. Prevalen Anemia Semasa Mengandung Dan Faktor-Faktor Mempengaruhinya Di Johor Bahru. Malaysian J Public Heal Med. 2010;10(1):70-83.

28. Afrino Re, Jannah R. Analisa Stressor Pada Ibu Hamil Primipara Terhadap Proses Persalinan. REAL Nurs J. 2019;2(3):86-98.

29. Jeong H, Ph D, Lim J, A B, Lee M, Ph D, et al. The association of psychosocial factors and obstetric history with depression in pregnant women : focus on the role of emotional support. Gen Hosp Psychiatry [Internet]. 2013;35(4):354-8. Available from: http://dx.doi.org/10.1016/j.genhosppsych.2013.02.009

30. Aktas S, Calik KY. Factors Affecting Depression During Pregnancy and the Correlation Between Social Support and Pregnancy Depression. 2015;17(9). 